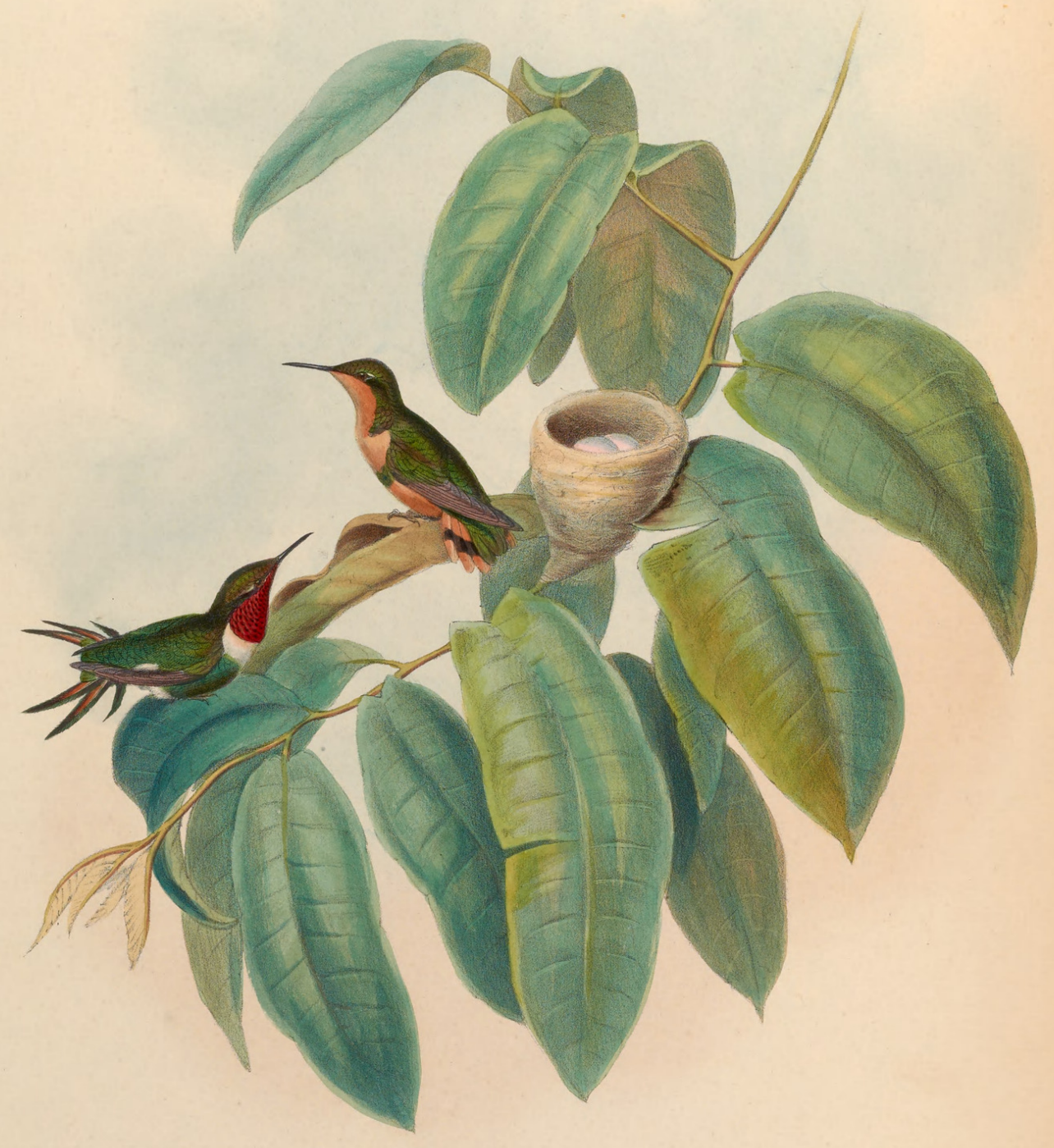

CALOTHORAX ROSAE. 


\section{CALOTHORAX ROSA.}

\section{Crimson-throated Wood-Star.}

Trochilus Rosa, Bourc. et Muls. Ann. de la Soc. Sci. de Lyons, tom. ix. 1846, p. 316.

Mellisuga rose, Gray and Mitch. Gen. of Birds, vol. i. p. 113, Mellisuga, sp. 64.

Calothorax Rosae, Reich. Aufz. der Col., p. 13.

Rosa, Bonap. Rev. et Mag. de Zool. 1854, p. 257.

IT cannot be said that our friends the French Trochilidists have been wanting in gallantry to the ladies when naming the new species they have acquired of this lovely group of birds, since, as will be seen, no inconsiderable number of them have been assigned appellations in honour of various members of the fairer portion of the community; consequently, complaint cannot be made that lordly man has engrossed all the honours. Thus the name of Rose has been applied by M. Bourcier, to the beautiful little Hummingbird figured on the accompanying Plate, in honour of Madame Rose Duquaire. Without intending any disrespect to the fair recipients of such honours, I cannot refrain from recording my dissent from this practice of naming species after individuals; it is true that $\mathrm{I}$ have done so myself in some few instances where it appeared unavoidable; nevertheless it is certainly one of those modes of complimenting persons which will be more honoured in the breach than in the observance. The bird in question, however, is certainly one of great beauty, and worthy in every respect to be dedicated to the fairest lady. It is a native of the Caraccas, where it appears to be common, the late Mr. Dyson having obtained numerous examples during his visit, and others having been procured by every collector who has explored that country.

Independently of the pure crimson colouring of its throat, which is of a deeper tint than in any other species, its singularly formed tail will constitute a specific character by which it may at all times be distinguished : these feathers, some of which are very short, present a split and ragged appearance, particularly the four longest of them, namely the two next the outer one on each side; the first or outer feather is extremely pointed, and not half the length of the next two, and the four middle ones are so short as to be almost hidden by the coverts. As will be observed on reference to the Plate, the female is totally different from the male both in her colouring and in the form of her tail.

The male has the head, all the upper surface, wing-and tail-coverts, four centre tail-feathers, flanks and abdomen, bronzy-green ; wings purple-brown; lateral tail-feathers purplish-brown, with a stripe of sandyred down the centre of the basal half of the two longer ones; on the chin and throat a gorget of the richest luminous crimson; across the breast a band of greyish-white.

The female has the whole of the upper surface, centre tail-feathers, wing-coverts and flanks golden-green ; wings purplish-brown; three outer feathers on each side sandy-buff, crossed obliquely by a broad mark of black; under surface deep buff.

The Plate represents the sexes of the natural size. 


\section{$2 \mathrm{BHL}$ Biodiversity Heritage Library}

Gould, John. 1855. "Calothorax rosæ, Crimson-throated Wood-Star. [PI. 149]." A monograph of the Trochilidae, or family of humming-birds 3, https://doi.org/10.5962/p.316958.

View This Item Online: https://www.biodiversitylibrary.org/item/109468

DOI: https://doi.org/10.5962/p.316958

Permalink: https://www.biodiversitylibrary.org/partpdf/316958

\section{Holding Institution}

Smithsonian Libraries

\section{Sponsored by}

Smithsonian Institution Libraries

\section{Copyright \& Reuse}

Copyright Status: NOT_IN_COPYRIGHT

This document was created from content at the Biodiversity Heritage Library, the world's largest open access digital library for biodiversity literature and archives. Visit BHL at https://www.biodiversitylibrary.org. 